NBER WORKING PAPER SERIES

RESOLVING THE GLOBAL IMBALANCE:
THE DOLLAR AND THE U.S. SAVING RATE

Martin S. Feldstein

Working Paper 13952

http://www.nber.org/papers/w13952

NATIONAL BUREAU OF ECONOMIC RESEARCH
1050 Massachusetts Avenue
Cambridge, MA 02138
April 2008

The views expressed herein are those of the author(s) and do not necessarily reflect the views of the National Bureau of Economic Research.

NBER working papers are circulated for discussion and comment purposes. They have not been peerreviewed or been subject to the review by the NBER Board of Directors that accompanies official NBER publications.

(C) 2008 by Martin S. Feldstein. All rights reserved. Short sections of text, not to exceed two paragraphs, may be quoted without explicit permission provided that full credit, including $\odot$ notice, is given to the source. 
Resolving the Global Imbalance: The Dollar and the U.S. Saving Rate

Martin S. Feldstein

NBER Working Paper No. 13952

April 2008

JEL No. F1,F3

\begin{abstract}
$\underline{\text { ABSTRACT }}$
The large trade and current account deficits of the United States cannot continue indefinitely because doing so would constitute a permanent gift to the U.S. economy. The process that will cause this gift to shrink and that will eventually cause it to reverse is a fall in the dollar. The dollar will fall as private investors and governments become unwilling to accept the risk of increasing amounts of dollars in their portfolios, especially in a context in which they realize that the dollar must fall to reduce the trade imbalance. Although a more competitive dollar is the mechanism that will cause the U.S. trade deficit to decline, the fundamental requirement for a lower trade deficit is an increase in the U.S. national saving rate. So a rise will be driven by higher household savings of the coming years as the two primary forces that depressed savings in recent years are reversed: the exceptionally rapid rise in household wealth and the high level of mortgage refinancing with equity withdrawal.
\end{abstract}

\author{
Martin S. Feldstein \\ President and Chief Executive Officer \\ NBER \\ 1050 Massachusetts Avenue \\ Cambridge, MA 02138-5398 \\ msfeldst@nber.org
}




\title{
Resolving the Global Imbalance: The Dollar and the U.S. Saving Rate
}

\author{
Martin Feldstein*
}

The massive deficit in the U.S. trade and current accounts is one of the most striking features of the current global economy and, to some observers, one of the most worrying. Although the current account deficit finally began to shrink in 2007, it remained at more than 5 percent of GDP — more than $\$ 700$ billion. While some observers claim that the U.S. economy can continue to have trade deficits of this magnitude for years — some would say for decades— into the future, I believe that such enormous deficits cannot continue and will decline significantly in the coming years.

This paper discusses the reasons for that decline and the changes that are needed in the U.S. saving rate and in the value of the dollar to bring it about. The dollar must decline substantially from its current value to shrink the trade deficit to a sustainable level. Although the dollar began to decline rapidly in the first quarter of 2008, the key exchange rate measure-the inflation-adjusted broad multilateral trade-weighted value of the dollar — was down at the end of 2007 by less than 6 percent from its value a decade earlier.

Reducing the U.S. current account deficit does not require action by the U.S. government

*Professor of Economics, Harvard University, and President and CEO, the National Bureau of Economic Research. Forthcoming in the Journal of Economic Perspectives 2008. 
or by the governments of America’s trading partners. Market forces alone will cause the U.S. trade deficit to decline further. In practice, however, changes in government policies at home and abroad may lead to faster reductions in the U.S. trade deficit. More important, the response of the U.S. and foreign governments and central banks will determine the way in which the global economy as a whole adjusts to the decline in the U.S. trade deficit.

Reductions in the U.S. current account deficit will of course imply lower aggregate trade surpluses in the rest of the world. Taken by itself, a reduction in any country's trade surplus will reduce aggregate demand and therefore employment in that country-something that no country wants. I will therefore look at what other countries_-China, Japan, and European countries_ — can do to avoid the adverse consequences of the inevitable decline of the U.S. trade deficit.

\section{Can the U.S. Current Account Imbalance Be Sustained?}

To understand why the U.S. current account deficit cannot go on as it is, it is helpful to look at the evolution of the deficit and of its financing. The U.S. current account deficit is not only large but has grown very rapidly. Even more important, it is being financed in a fundamentally different way now than it was just a few years ago.

The annual current account deficit peaked in 2006 at \$811 billion. Even after adjusting

for the rising price level, the real current account deficit was up 84 percent in five years and was more than five times its level ten years earlier. The current account deficit declined in 2007 to $\$ 739$ billion, an 11 percent real decline. But even after this improvement, U.S. merchandise 
imports were more than $\$ 1$ trillion greater in 2007 than in 1997 while merchandise exports were up by less than half that amount. During the same decade, U.S. net exports of services—which include financial services, transportation, and tourism—remained essentially unchanged.

A nation that buys more than it sells must finance the difference by borrowing from the rest of the world or by selling assets. As recently as the year 2000, the United States was able to finance its entire current account deficit by attracting equity investments to the United States.

In that year, net stock purchases by foreigners were $\$ 192$ billion while foreign direct capital investments were $\$ 289$ billion. The total of $\$ 481$ billion exceeded the current account deficit of $\$ 417$ billion and was about three times the $\$ 162$ billion inflow of debt. ${ }^{1}$ Foreigners bought shares of American corporations on the stock market or bought entire businesses (like Daimler buying Chrysler and Deutsche Bank buying Bankers Trust). Private funds came to the United States in this way because they expected to receive returns that outweighed the risks of cross-border investments. The situation has changed dramatically. The 2007 equity inflow to the United States, including net share purchases and foreign direct investment, was only 52 percent of the $\$ 739$ billion current account deficit and about the same size as the inflow of debt. The net purchases of stock were only $\$ 183$ billion or about half of the inflow in the form of bond purchases.

\footnotetext{
${ }^{1}$ For these data on capital flows, see the webpage for the U.S. International Transactions Accounts Data from the Bureau of Economic Analysis at $<$ http://www.bea.gov/international/bp_web/list.cfm?anon=71\&registered=0 $>$.
} 
We don't know with certainty who the buyers of U.S. stocks and bonds are, but I believe that they are primarily governments or government-related entities. We don't know the identity of the buyers because the official U.S. Treasury data on capital flows only tell us who does the trade and not the actual beneficial owner. For example, if a Middle East government uses a British bank to buy U.S. Treasury bonds, the transaction is recorded as the purchase by a private British buyer (Feldstein, 2005).

But the very fact that so much of the financing flow has gone from shares to bonds is a clear indication that these funds are coming from governments rather than private investors. And we have the corroborating evidence of the massive increases in the official foreign exchange reserves of the countries with large current account surpluses. China has more than $\$ 1$ trillion dollars of reserves, Japan more than $\$ 500$ billion, Korea more than $\$ 150$ billion, Russia more than $\$ 200$ billion and the oil-producing countries more than $\$ 200$ billion (Council of Economic Advisers, 2008, table B-111). Most of these reserves have been accumulated since the year 2000. This change in the way the current account deficit is being financed has important implications for its sustainability. It is no longer possible to say, as it was back in the year 2000, that the U.S. current account deficit is sustainable because it is being financed by private investors who are attracted by the productivity and profitability of the U.S. economy. The funds are coming into the U.S. economy now because foreign governments are willing to buy amounts of debt that can finance the U.S. current account deficit. The foreign governments are willing to do that to sustain their export surpluses with the United States. But how long will they be willing to continue to do so?

The current trade imbalance has been a very favorable arrangement for the United States. 
The U.S. economy receives goods and services from the rest of the world and gives them back IOUs in the form of government and corporate debt. In 2007, the U.S. economy received $\$ 708$ billion more in goods and services than America sent to the rest of the world, and all that the U.S. economy had to give in exchange for these net imports was $\$ 708$ billion of IOUs. Over the past five years, the U.S. economy has traded several trillion dollars of IOUs for that much in real goods and services. And when these IOUs come due, the U.S. economy only gives new IOUs in exchange. The same is true for the interest that the U.S. economy owes on the IOUs. While it would certainly be nice for the United States if this economy could continue indefinitely to receive more goods and services from the rest of the world than it sends back, this is simply not going to happen. If it did happen, these U.S. net imports would constitute a giant gift.

The only way for the United States to repay some of this cumulative gift is for U.S. exports to the rest of the world to exceed imports. Since I cannot believe that the world will continue to give the United States an enormous gift year after year, I am convinced that at some point in the future, our trade deficit will end and the U.S. economy will have a trade surplus. We have a long way to go before that happens - - that is before the $\$ 708$ billion trade deficit turns into a trade surplus. But it will happen. And while a U.S. trade surplus may now strike readers as implausible, isn't it more implausible that the world will give the U.S. economy an enormous gift each year though it will never get anything back in exchange?

Long before the U.S. economy reaches the time when it will have a trade surplus, the U.S. trade deficit will decline. U.S. imports will shrink and exports will increase. What is the mechanism by which this will occur? The key is the future decline in the dollar relative to the foreign currencies that will occur as foreign investors, both public and private, become less 
willing to keep adding dollar bonds to their portfolios.

Foreign governments that artificially depress their currencies in order to run large trade surpluses and therefore accumulate dollar investments are foregoing the opportunity to invest those resources in their domestic economy. Their real return on dollar bonds is less than 3 percent even if the dollar does not decline, while direct investment in their own economies can be expected to produce substantially higher real returns (Dollar and Wei, 2007). The oilproducing countries are already making plans to shift from portfolio investments to substantial infrastructure investments in their own countries, increasing imports instead of sending surplus savings abroad.

There are two further reasons why foreign investors will reduce their demand for dollar bonds. Prudent investors know that portfolios should be diversified. The Chinese, with about $\$ 1$ trillion of U.S. bonds, are taking a risk that would have to be called imprudent. Shifting a portion of that to equity investments, as the Chinese are now beginning to do, does not fundamentally reduce their exposure to the level of the dollar and to the correlated risks between dollar interest rates and U.S. equity prices. Even if the Chinese think the dollar is as likely to rise as to fall in the near term, it is very risky to have such a large amount of dollar investments. The value of the dollar portfolio is equal to about $\$ 1,000$ per person in China, about the level of the total per capita income in China at the official exchange rate.

But the primary reason why it would be unwise for foreign portfolio investors to continue to accumulate dollar securities is that the dollar must eventually decline as part of the trade adjustment process. Any investor who expects the value of the dollar to decline relative to other major currencies would want to shift from investing in dollars to investing in those other 
currencies. While investors like China that have a very large amount of foreign exchange invested in dollars would have reason to fear that selling dollar bonds and buying bonds denominated in other currencies might hurt themselves by causing the value of the dollar to decline, those countries with smaller dollar balances can shift to euros or yen without such fears. In turn, the knowledge that others are selling will force even large investors like China to realize that they will face a loss if they do not diversify away from dollar bonds.

Central banks and other investors can be induced to hold a large amount of a currency that is expected to decline if the interest rate on that currency is sufficiently high. But the interest rates published in the weekly Economist magazine show that the interest rate on dollar bonds is now actually less than the interest rate on euro bonds with similar default risk. There is no compensation in these interest rates for the potential decline of the dollar that will be necessary for the ratio of U.S. external debt to stop rising. Any investor that shifted from dollar bonds to euro bonds a year ago would have received slightly lower interest income (because euro interest rates only recently exceeded those on dollar bonds) but would have seen a rise in the dollar value of their assets of more than 15 percent. For example, $\$ 100$ would have grown to less than $\$ 105$ if invested in U.S. Treasury bonds but to more than $\$ 115$ if invested in comparable euro bonds and then converted back into dollars.

Although most central banks are reluctant to discuss the composition of their foreign exchange reserves, some relatively large central banks have disclosed that they have begun to reduce the share of dollars in their portfolios. ${ }^{2}$ The low level of foreign investments in U.S. equities suggests that private investors have also been reducing the share of dollar securities in

\footnotetext{
${ }^{2}$ This evidence is reported by the IMF in its "COFER: Currency Composition of Foreign Exchange Reserves" webpage at <http://www.imf.org/external/np/sta/cofer/eng/index.htm>.
} 
their portfolios.

But as long as the United States has a large trade deficit, the U.S. economy must continue to attract sufficient funds from foreign sources to finance the trade and current account deficits. While any individual private or public investor can shift away from dollars, foreign investors as a whole cannot sell the dollars that they have accumulated and must continue to supply the additional dollars needed to fund the ongoing current account deficits.

How does this situation get reconciled? If governments and private investors are unwilling to buy dollar bonds because they fear or expect a future dollar decline, the dollar must fall enough so that they are no longer expecting a further fall—or, more accurately, until the expected annual fall in the dollar is no larger than the extra interest rate that investors get for investing in dollar funds.

The specific mechanism that will cause the dollar to decline is this: When foreign exporters get dollars by selling products to U.S. buyers, they bring those dollars to their commercial banks and ultimately to their central bank to exchange them for their local currency. If the central bank does not want to add those dollars to existing foreign exchange reserves, it will try to sell them. If there are not willing buyers at the prevailing exchange rate, the dollar will fall until it becomes attractive enough to some potential buyers. Similarly, if an investor or a central bank wants to reduce its existing holding of dollars, it must try to sell those dollars in the market. If there are not willing buyers at the existing exchange rate, the value of the dollar must fall.

In recent years, the demand for dollars has been sustained by the desire of some central banks to accumulate large amounts of foreign exchange to protect themselves against the 
speculative attacks of the type that occurred in the late 1990s. Korea, Taiwan, and others have therefore accumulated such large amounts that no private speculator would consider trying to attack their currency, as long as it was not fundamentally overvalued. Having now acquired more than enough funds for this purpose, these countries no longer have such a counterspeculative motive for further accumulation of dollars.

Some central banks, most notably the Chinese and Japanese, have also pursued a strategy of keeping their currency undervalued as a way to stimulate a trade surplus. While this strategy may be reasonable in the short run to increase aggregate demand and employment, it makes no sense in the long run to stimulate exports in exchange for perpetual IOUs when a similar stimulus to aggregate demand and employment could be achieved by better domestic policies, a subject to which I return below.

In summary, the large trade and current account deficits of the United States cannot continue indefinitely because doing so would constitute a permanent gift to the U.S. economy. The process that causes this gift to shrink and that will eventually cause it to reverse is a fall in the dollar. The dollar will fall as private investors and governments become unwilling to accept the risk of increasing amounts of dollars in their portfolios, especially in a context in which they realize that the dollar must fall to reduce the trade imbalance.

\section{The Role of National Saving}

Although a more competitive dollar is the mechanism that will cause the U.S. trade deficit to decline, the fundamental requirement for a lower trade deficit is an increase in the U.S. 
national saving rate. For any country, national saving is the difference between what that country produces (its GDP) and what it consumes (both household consumption and government consumption). The output that is produced but not consumed (and thus is saved) can be used for investment in business equipment, housing, and other structures, or it can be exported to the rest of the world. This is a basic implication of the national income accounts identity that saving minus investment equals exports minus imports.

In the United States, saving is now so low that America must import from the rest of the world to have enough product to invest in domestic equipment and structures. More specifically, despite the relative decline in both business investment and housing construction, their combined level exceeds national saving, forcing the U.S. to import more than it exports. Low national saving is the fundamental cause of the U.S. trade deficit. ${ }^{3}$

National saving includes both household saving and the saving of corporate businesses (their retained earnings) and is reduced by government dissaving (when the government runs budget deficits). The primary reason for the present low national saving rate in the United States is the current saving behavior of households. Business saving has been quite high, reflecting the relatively high level of profits. And the government deficit, although potentially heading for trouble in the next decade because of the rising cost of government pensions and health care for the aged, is now quite low at less than 1.5 percent of GDP. (These saving rates, as recorded in

\footnotetext{
${ }^{3}$ Although the ability of the U.S. economy to attract large amounts of capital is helped by the large amounts of saving in other countries (especially China and the oil producers), those funds come to the United States because of the gap between U.S. investment and U.S. saving instead of going to other parts of the world. The availability of large amounts of saving in other countries has been described by some as a "saving glut," although in reality global saving has not increased. The non-U.S. excess of saving over investment is due to a relatively lower level of investment (Feldstein, 2006).
} 
the national income and product accounts, are available each year in the annual Economic Report of the President.)

But household saving in the U.S. economy is now essentially zero-just 0.5 percent of disposable personal income in 2007. The saving of those households that do save-that is, those who spend less than their after-tax incomes_-is just about balanced by the dissaving of those households that dissave by borrowing or running down existing assets.

Because the trade deficit is the difference between national investment and national saving, reducing the trade deficit requires an increase in the U.S. saving rate or an equally large fall in business investment and residential construction. The recent sharp fall in housing construction has reduced overall investment and permitted a modest decline in the trade deficit. I believe that over the longer term, the adjustment will come primarily through a higher saving rate and that this will happen without any specific change in government policy. The household saving rate will rise because the two primary forces that have driven savings down to the current level—-the exceptionally rapid rise in household wealth and, 2) more recently, the high level of mortgage refinancing with equity withdrawal-will come to an end. The Flow of Funds data available from the Federal Reserve at <http://www.federalreserve.gov/releases/z1> provide evidence on the rise of household wealth and the sharp increase in mortgage borrowing in the early part of the current decade.

The sharp rise in wealth is being checked by the decline in home prices that has recently begun and that is likely to continue for some time (Shiller, 2007). The prices of stocks are also not likely to outperform earnings in the future in the way that they have been doing. And mortgage refinancing will not generate spendable cash for households as it has in the past 
because fewer households have existing mortgages with rates that exceed the rates available on new mortgages and because the aggregate value of net housing equity that can be accessed by borrowing is in decline.

The increase in saving (or, more accurately, of saving relative to investment) is a necessary condition for reducing the trade deficit, but it is not sufficient. Households and businesses in the United States and abroad must be also have an incentive to spend more on American-made goods and services and less on the goods and services made elsewhere in the world. That incentive, of course, is a change in the relative prices of American and foreign goods and services. This change will come about through a decline in the value of the dollar relative to the value of other major currencies, including the euro, the yen, the Chinese yuan, the British pound, and others. When the dollar declines relative to the euro, as it has been over the past year, American goods become cheaper relative to European goods. That change pushes American households and businesses to buy less in Europe and more in America. The same happens in reverse for European buyers. ${ }^{4}$

\footnotetext{
${ }^{4}$ It is of course possible in theory for the relative prices of American and foreign goods to change without any change in the nominal exchange rate. If the prices of all American goods and services were to fall by (say) 20 percent while the exchange rates remained unchanged, that would achieve a 20 percent real devaluation of the dollar. That would have the same effect as a 20 percent fall in the nominal exchange rate while the prices of U.S. and foreign goods remained unchanged (or rose together at the same rate). It is the theoretical possibility of such a decline of the dollar's real value without a fall in its nominal value that causes some economists to say that the trade deficit can decline substantially without a fall in the dollar. There is, of course, no chance that U.S. prices would actually fall by anything like that. Similarly, while a 20 percent rise in all foreign prices would also cause such a change in the real exchange rate if nominal exchange rates remained unchanged, there is no chance of such an inflationary shift now that most countries are managing monetary policy to keep inflation very low. In short, changing relative prices will require a change in the nominal exchange rate.
} 
Some people worry that even a large decline in the value of the dollar would not be able to change purchasing patterns enough to reduce the U.S. trade deficit. It is common to hear the concern that the U.S. economy no longer has the ability to manufacture and export, or the worry that it will never be able to compete with the low labor costs that drive imports from countries like China or Vietnam.

Both of these worries are unfounded. The U.S. economy is a major exporter, selling more than $\$ 1$ trillion of goods to the rest of the world each year. As a lower dollar causes the price of those goods to become more competitive relative to the goods made in other countries, U.S. exports will rise more rapidly. Caterpillar tractors compete with the Komatsu tractors made in Japan. Boeing airplanes compete with European Airbus planes. California wine competes with wine from France and other euro countries. And as the dollar declines, these U.S. products will be more attractive to buyers at home and abroad.

About half of U.S. imports come from high-wage countries including Canada, western Europe, and Japan. A lower dollar relative to those currencies will cause a substitution of American-made goods for the similar goods that the U.S. economy now imports from abroad.

But what about the goods that come from countries in which wages are very low? It is certainly true that American workers will not be able to compete in the production of such lowcost goods. We will not see American factories making the products now produced in very lowcost factories in some Asian countries. But instead of substituting American-made goods for very similar imports, the lower dollar will cause Americans to buy a different mix of goods and services that are produced in the United States. As the dollar declines relative to the Chinese yuan, the Korean won, and the Thai bhat, the dollar prices of those products will rise. American 
consumers will find them less attractive at those higher prices and will shift to buying U.S. goods and services. Much of that substitution will be to services that can only be produced in the U.S. and cannot be imported. For example, as imported clothing and electronic equipment become more expensive, American consumers will spend more on meals away from home and on local travel and entertainment in the United States.

Some skeptics about the ability of the dollar to shrink the trade deficit point to the fact that the trade deficit increased until 2006 despite a 7 percent decline during the previous three years in the real trade-weighted value of the dollar. There are four distinct reasons for this apparent lack of responsiveness: First, the rise in the price of oil increased the total U.S. outlays for imported oil. Second, imports and exports only respond to a lower dollar with some delay because of buying habits and institutional arrangements. Third, and more fundamentally, U.S. imports rise more rapidly when American incomes increase than the imports of America's trading partners do when their incomes rise, reflecting the fact that foreign purchases from the United States involve relatively large quantities of agricultural products and other goods with relatively low income elasticities of demand. This pattern implies that even if U.S. incomes and those in the rest of the world rose at the same rate, it would require a falling dollar just to keep the U.S. trade deficit from rising. Finally, the trade gap is difficult to close because U.S. imports are currently more than 70 percent larger than exports, implying that it takes an even larger proportionate rise in exports just to keep the trade imbalance from rising. For all of these reasons, reducing the trade deficit will require a large reduction in the dollar relative to that of other currencies.

Why has the dollar not declined more rapidly relative to the euro, and why has it hardly 
declined at all relative to the Japanese yen and the Chinese yuan? A decline of the dollar would naturally be driven by the combination of an expectation that the dollar must eventually fall to shrink the trade deficit and the current positive difference between interest rates on euro bonds and dollar-denominated bonds. A variety of forces have delayed the full adjustment of the dollar. These include the misleading statements of governments (including the familiar statement of all the U.S. Treasury secretaries since Robert Rubin that “A strong dollar is good for America”), by international financial institutions (like the IMF), and by some economists that suggest that the imbalances can be eliminated without a decline of the dollar. But the most obvious reason for the dollar's lack of adjustment has been the policies of the Chinese and Japanese governments aimed at keeping their currencies undervalued.

\section{Reducing China's Trade Surplus}

The Chinese have achieved an enormous and growing trade surplus (now equal to 7 percent of China’s GDP) by keeping their currency, the yuan, artificially depressed. ${ }^{5}$ Until 2005, the yuan was fixed relative to the dollar, and since then it has been allowed to appreciate by only about 5 percent a year. Because the euro has risen substantially more during the same period, the yuan has had little change on a trade-weighted basis. Moreover, since the prices of Chinese exports have fallen relative to the U.S. price level, the real value of the yuan has actually declined relative to the dollar.

\footnotetext{
${ }^{5}$ The trade surplus of China and other countries is reported weekly in The Economist magazine, both in dollars and as a percentage of the country's GDP. For a broader review of current information on the Chinese economy, see the World Bank's China Quarterly Update, available at <http://www.worldbank.org/cn>. 
To keep the yuan from appreciating, the Chinese central bank has had to purchase not only all of the foreign exchange generated by China's enormous trade surplus, but also the funds that have come to China in anticipation of a future currency appreciation. The result has been a rise in China’s foreign exchange reserves to more than $\$ 1$ trillion, an amount that is likely to increase in 2008 by an additional several hundred billion dollars.

The Chinese have kept the yuan undervalued despite calls for greater currency flexibility from the United States, the G-7 (a group of high-income countries including Canada, France, Germany, Italy, Japan, United Kingdom, and the United States), and the International Monetary Fund because of a fear that a stronger yuan will cause a decline in exports that will make it more difficult to create the large number of jobs required to absorb the growing population and the shift of the labor force from agriculture to industry. China has agreed to move to a more flexible exchange rate and has recently widened the daily limit in the movement of the currency, although without actually allowing it to appreciate that much. China has also established a goal in its recent five-year plan of eliminating the trade surplus, although again without taking significant steps to achieve that goal.

The key to shrinking China’s trade surplus is to reduce the remarkably high national saving rate, currently more than 40 percent of GDP. Reducing the saving rate can be achieved by increasing both household consumption and the level of government spending on public programs in health and education. Both of these changes would create the additional demand needed to absorb the growing nonagricultural labor force. Moreover, an increase in household consumption is appropriate because household consumption and incomes have not been growing nearly as fast as GDP in recent years, implying that households have not shared in the increasing 
affluence of the nation. China's goal of achieving a more "harmonious growth" by raising the living standard in rural, western, and interior regions and in the lower-income groups in urban China would also be served by a pro-consumption policy.

China's officials recognize that both primary and secondary education in the rural areas, where more than two-thirds of the population now live, have declined significantly since the labor market reforms no longer permit forcing young college graduates to go as teachers to the countryside. It is also clear that health services everywhere are grossly inadequate for a nation of rising incomes and aspirations.

China’s current fiscal condition—a relatively low level of national debt and official annual deficits of only about 1 percent of GDP—should permit pro-consumption tax policies and increased government spending. Even if China raised its fiscal deficit to as much as 3 percent of GDP, the ratio of national debt to GDP would be declining because of China's rapid growth rate. Moreover, China’s official budget deficit figure does not take into account the earnings retained by state-owned enterprises or partially state-owned enterprises. If that income is taken into account, China now has a fiscal surplus.

Several policies could increase consumer spending. A better mortgage market and a consumer credit market would allow individuals to pay for durable products as they consume them instead of having to save in advance. A better health insurance market would reduce the need for individuals to accumulate funds in anticipation of potential medical expenditures. An expanded Social Security retirement system would reduce household retirement saving.

While China has the largest global trade surplus of any country, other countries must also reduce their trade surpluses as part of global adjustment. They too can do this without reducing 
domestic employment and growth if they pursue appropriate fiscal and regulatory policies. Japan, for example, could offset higher interest rates and a stronger yen by adopting revenueneutral tax changes that stimulate consumption and business investment. A temporary investment tax credit financed by a concurrent higher corporate tax rate would not change the budget deficit but would cause a higher level of investment. A cut in the personal tax rate that is balanced with a concurrent gradual rise in the value-added tax would encourage more short-run spending, too.

While Europe as a whole does not have a trade surplus, part of the reduction in the U.S. trade deficit will be felt in Europe. To offset the decline in European exports, the individual countries of Europe could also adopt revenue-neutral fiscal policies to raise consumer spending and investment.

It is important to begin focusing on these reforms before the growing international imbalances cause a much more painful adjustment of domestic spending and employment.

\section{The Inadequacy of the IMF Multilateral Surveillance Process}

The International Monetary Fund decided in 2006 to go beyond its usual advice to individual countries in an attempt to achieve a coordinated action to reduce the global imbalances (IMF, 2006). I believe that the IMF's approach will not succeed in achieving any reduction in the U.S. trade deficit and the corresponding trade surpluses around the world. The key missing ingredient in the IMF advice is a recognition that resolving the global trade imbalance requires a fundamental realignment of currencies, with a substantial decline of the 
dollar relative to the euro, the Japanese yen, the Chinese yuan, and other Asian currencies. The actions that the IMF has called for are ones that the key countries can claim that they are already doing.

According to the IMF guidelines, the U.S. government should reduce its fiscal deficit and thereby shrink the U.S. demand for imports. The IMF urges the European governments to follow the "Lisbon Agenda” (described at <http://europa.eu/scadplus/glossary/lisbon_strategy_en.htm>), which is a set of policies intended to promote a dynamic knowledge-based economy in Europe to accelerate economic growth and thereby raise imports. The oil-producing countries are told to invest in increased oil production capacity, presumably leading to a lower price of oil and therefore reduced oil revenue. For its part, China should allow a more flexible exchange rate.

These proposed policies are unlikely to induce significant changes in behavior. The United States can point to the progress that is already being made in reducing the fiscal deficit, coming down from 2.5 percent of GDP in 2005 to less than 1.5 percent in the 2007 fiscal year. The European governments can assert that they are already pursuing the Lisbon Agenda. The OPEC countries can point to the substantial investments that they are making in exploration and drilling. China can note that it has widened the dollar-yuan exchange rate band and allowed the yuan to appreciate by more than 10 percent over the past two years. Each of the participants can therefore assert that it is already complying with the proposals of the IMF.

Even if the IMF did succeed in changing behavior along the lines that they advocate, it is not clear that this would reduce global imbalances. A rise in U.S. national saving without a concurrent increase in the competitiveness of the dollar-something the IMF does not 
advocate—-would lead to lower economic activity and higher U.S. unemployment with little effect on the current account imbalance. Moreover, a lower fiscal deficit in the United States that is achieved by repealing the current favorable tax rates on dividends and capital gains could cause household saving to fall, leaving national saving no higher than before. While an increase in European growth would raise imports if the greater output reflected higher aggregate demand, the opposite could be true if an increase in growth were caused by greater productivity, the goal of the Lisbon Agenda. Greater productivity would raise supply relative to demand and permit lower real prices, leading to increased European exports. An increase in oil-producing capacity could lead to lower prices, but the combination of the lower price and the increased quantity could raise the total OPEC revenue, increasing the total imbalance. An increase in the flexibility of the Chinese exchange rate that caused Chinese goods to be more expensive would help to reduce the trade deficit. But despite the enormous size of the Chinese trade surplus, it would take a very large increase in the yuan alone to cause a significant reduction in the overall trade imbalance if other currencies did not also appreciate.

While the need for a more competitive dollar as a key to shrinking the trade deficit is clear to most professional economists, the IMF officials and the political leaders who participate in the G-7 process are reluctant to speak about the exchange rate out of fear that they will trigger a much larger movement that will destabilize domestic activity in key countries. While this reluctance is understandable, it has lead to increasingly large imbalances that run the risk of causing greater instability when they are resolved. It now threatens to lead to currency intervention that will, if successful, only postpone the ultimate resolution of the global imbalances. 


\section{References}

Council of Economic Advisers. 2008. Economic Report of the President. Washington, DC: U.S. Government Printing Office.

Dollar, David, and Shangjin Wei. 2007. "Das Wasted Kapital in China: Firm Ownership and Investment Efficiency in China." National Bureau of Economic Research Working Paper 13103.

Feldstein, Martin. 2005. "Monetary Policy in a Changing International Environment: The Role of Global Capital Flows.” National Bureau of Economic Research Working Paper 11856.

Feldstein, Martin. 2006. "The 2006 Economic Report of the President: Comment on Chapter One (The Year in Review) and Chapter Six (The Capital Account Surplus).” Journal of Economic Literature, 44(3): 673-79.

IMF. 2006. "IMF to Begin Multilateral Consultations with Focus on Global Imbalances.” IMF Press Release No. 06/118, June 5. At $<$ http:///www.imf.org/external/np/sec/pr/2006/pr06118.html>.

IMF. 2008. "Currency Composition of Official Foreign Exchange Reserves (COFER)" $<$ http://www.imf.org/external/np/sta/cofer/eng/index.htm>.

Shiller, Robert. 2007. "Understanding Recent Trends in House Prices and Home Ownership.” National Bureau of Economic Research Working Paper 13553. (Forthcoming in Housing, Housing Finance and Monetary Policy, Federal Reserve Bank of Kansas City.) 